\title{
Studies on Wicking Behaviour of Polyester Fabric
}

\author{
Arobindo Chatterjee and Pratibha Singh \\ Department of Textile Technology, National Institute of Technology, Jalandhar 144 011, India \\ Correspondence should be addressed to Arobindo Chatterjee; chatterjeea@nitj.ac.in
}

Received 5 October 2013; Accepted 7 January 2014; Published 24 February 2014

Academic Editor: Seshadri Ramkumar

Copyright (C) 2014 A. Chatterjee and P. Singh. This is an open access article distributed under the Creative Commons Attribution License, which permits unrestricted use, distribution, and reproduction in any medium, provided the original work is properly cited.

\begin{abstract}
This paper aims to investigate vertical wicking properties of polyester fabric based on change in sample direction and change in tension. Also experimental results are compared with theoretical results. Polyester fabric made out of spun yarn with four types of variation in pick density was used. Theoretical values of vertical wicking were calculated by using Lucas-Washburn equation and experimental results were recorded using strip test method. Maximum height reached experimentally in both warp way and weft way is more than that of the theoretical values. The maximum height attained by fabric experimentally in weft is more as compared to warp way. Vertical wicking increases with increase in tension. This paper is focused on wicking which plays a vital role in determining comfort and moisture transport behavior of fabric.
\end{abstract}

\section{Introduction}

Transport of water through textiles plays a very important role in deciding comfort, dyeing and finishing of textile fabrics, liquid filtration, and so forth. Transport of water takes place through the phenomenon of capillarity. Capillarity is the ability of liquids to penetrate into fine pores with wettable walls and be displaced from those with nonwettable walls [1]. Capillary wetting is due to the meniscus formed by fibres and yarns in warp and weft directions, especially in the interstitial area [2].

Wicking can only occur when a liquid wets fibres assembled with capillary spaces between them. The resulting capillary forces that arise from the wetting of the fabric surface due to pressure difference created by surface tension of the liquid across the curved liquid/vapor interface drive the liquid into the capillary spaces. Because capillary forces are caused by wetting, wicking is a result of spontaneous wetting in a capillary system [3]. Capillary forces are governed by the properties of the liquid, liquid-medium surface interactions, and geometric configurations of the pore structure in the medium.

During normal activity and in normal atmospheric condition, the heat produced in the body due to metabolism is liberated to the atmosphere by conduction, convection, and radiation and the body perspires in vapour form to maintain the temperature. However, while doing high level bodily activity and/or at higher atmospheric temperatures, heat production is very high and for transmitting this heat from the skin to the atmosphere the sweat glands produce liquid perspiration (insensible perspiration which is in vapour form and sensible perspiration which is in liquid form) [4]. To be in comfortable state, the clothing worn should allow both types of perspirations to transmit from the skin to the outside atmosphere. Moisture related properties influence the thermophysiological clothing comfort of the material [5].

Mathematical modeling of surface-tension-driven flow in yarns and fabrics can provide a way to develop an understanding of the liquid transport mechanism. The constituent yarns are responsible for the main portion of the wicking action, in capillary flow through textile fabrics [6,7]. In many researches, the textile yarns were treated either as porous media [8-10], the liquid transport through which is described by Darcy's law [11], or as capillary tubes [12-15], the liquid flow through which can be modeled by Lucas-Washburn kinetics [16]. In the first case, the characteristic parameters, such as permeability, are difficult to quantify and are obtained empirically. In the second case, the effective radius of the capillary tube, the effective contact angle, and so forth are determined by fitting the experimental data [17]. 
TABLE 1: Details of sample used for experiment.

\begin{tabular}{|c|c|c|c|c|c|c|}
\hline Composition & Type of yarn & EPI & PPI & Thickness (in mm) & GSM & Referred to as \\
\hline $100 \%$ polyester & Staple yarn & 48 & 30 & 0.535 & 127 & P1 \\
\hline $100 \%$ polyester & Staple yarn & 48 & 40 & 0.493 & 147 & $\mathrm{P} 2$ \\
\hline $100 \%$ polyester & Staple yarn & 48 & 50 & 0.544 & 173 & P3 \\
\hline $100 \%$ polyester & Staple yarn & 48 & 60 & 0.549 & 186 & $\mathrm{P} 4$ \\
\hline
\end{tabular}

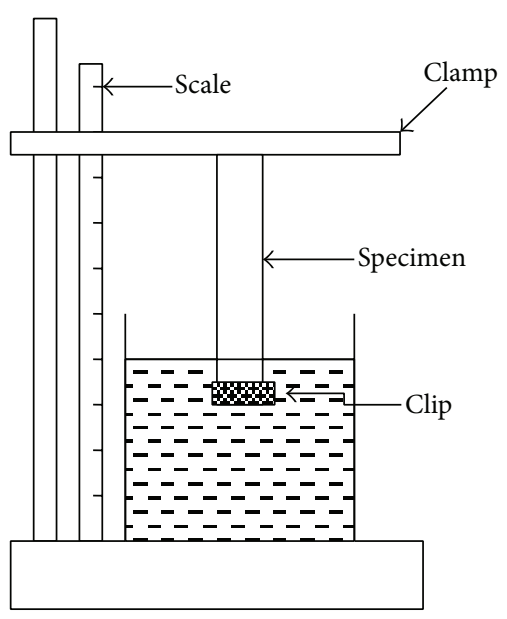

Figure 1: Vertical wicking apparatus.

In a model developed for jersey knitting fabric macroand microcapillary are considered which are collectively responsible for wicking in the fabric. The effective capillary radius is not calculated by fitting the experimental data; it is dependent on the geometrical conformation [18]. It was reported by various researchers that wicking depends on tortuosity of fabric $[6,7,14,19]$ and this factor was incorporated in single jersey knitted fabric [18].

Though this work focuses on the wickability, recently related properties such as moisture vapor transport have also attracted attention [20-22].

In this work, plain woven fabric is studied and tortuosity factor is considered. Direct method for calculation of macropore radius is given for plain weave.

\section{Materials and Methods}

2.1. Materials. Fabric was made out of $100 \%$ polyester spun yarn having $2 / 30$ 's yarn count. The detailed specification of it is given in Table 1 .

\subsection{Methods}

2.2.1. Vertical Wicking. The schematic diagram of the experimental setup for measurement of vertical wicking is shown in Figure 1. The fabric was tinted to facilitate visual tracking of the movement of water.

Specimens of $200 \mathrm{~mm} \times 25 \mathrm{~mm}$ cut along warpwise and weftwise directions were prepared from these fabrics. The specimens were suspended vertically with their bottom ends dipped in a reservoir of distilled water. In order to ensure that the bottom ends of the specimens could be immersed

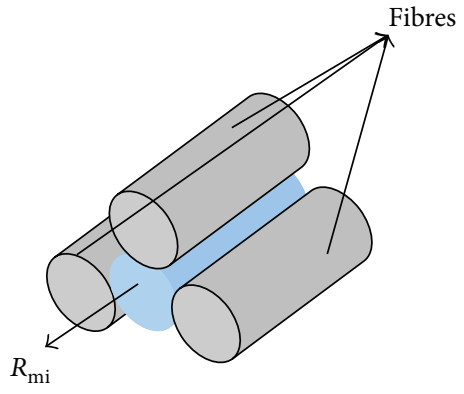

FIgure 2: Microcapillary.

vertically at a depth of $20 \mathrm{~mm}$ into the water, the bottom end of each specimen was clamped with a $3 \mathrm{~g}$ clip. To evaluate wicking performance at varying tensions $3 \mathrm{~g}$ weight was replaced by $12 \mathrm{~g}, 20 \mathrm{~g}$, and $34 \mathrm{~g}$ weights. For kinetics of wicking heights, distance traveled by water on vertical strip was measured for every minute for the first 5 minutes and then readings were taken after every 5 minutes for 30 minutes.

The fabric wicking experiments were conducted in a standard atmosphere of $20 \pm 2^{\circ} \mathrm{C}$ and $65 \pm 2 \%$ relative humidity and the fabric was conditioned for $24 \mathrm{~h}$ before testing.

2.2.2. Capillary Rise in Fabric. Textile materials are hierarchical porous media. Fabric is composed of yarns which are running parallel to each other and yarns are made up of fibres or filaments oriented along the yarn axis. Capillary rise in fabric can be considered as the effect of capillary rise between yarns within a fabric and between fibres within a yarn constituting the fabric. The capillary formed between yarns may be termed as macrocapillary and capillary formed between fibres in yarn may be termed as microcapillary. Microcapillary, macrocapillary, and tortuosity were evaluated for theoretical calculation of capillary rise using Lucas-Washburn equation.

Microcapillary. Capillary rise between fibres (in a yarn) can be analysed like a flow in capillary tube of radius $R_{\mathrm{mi}}$ as shown in Figure 2.

The capillary rise of liquid is given by Washburn law [16] as follows:

$$
\frac{d h}{d t}=\frac{\left(R_{\mathrm{mi}} / \tau\right)^{2}}{8 \eta h}\left(\frac{2 \gamma_{L} \cos \theta}{R_{\mathrm{mi}}}-\rho g h\right),
$$

where $d h / d t$ is the rate of change of capillary height with respect to time, $R_{\mathrm{mi}}$ is the microcapillary radius, $\tau$ is the tortuosity, $\eta$ is liquid viscosity, $h$ is the capillary height, $\gamma_{L}$ is surface tension, $\cos \theta$ is the contact angle of water with the fibre, $\rho$ is liquid density, and $g$ is acceleration due to gravity. 


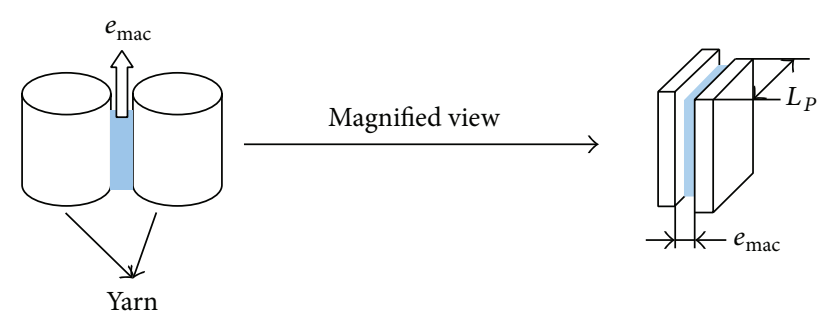

FIGURE 3: Macrocapillary.

At equilibrium the rate of change of height with respect to time is zero. That is, $d h / d t=0$. Putting this value in (1) we get:

$$
h_{\text {mic-eq }}=\frac{2 \gamma_{L} \cos \theta}{R_{\mathrm{mi}} \rho g} .
$$

From (1), (3) can be obtained for further evaluation of kinetics of capillary rise as follows:

$$
h=\frac{2 \gamma_{L} \cos \theta}{R_{\mathrm{mi}} \rho g}\left(1-\frac{1}{e^{\left(t R_{\mathrm{mi}}^{2} \rho g / \tau^{2} 8 \eta\right)}}\right) .
$$

Microcapillary radius $\left(R_{\mathrm{mi}}\right)$ can be calculated as [18]

$$
R_{\mathrm{mi}}=\sqrt{\frac{t^{2}}{32 n_{s}}-\frac{d_{\text {fiber }}^{2}}{8}} .
$$

Macrocapillary. On fabric scale the capillary formed is between yarns as shown in Figure 3.

The equation describing the capillary kinetics of progression between two parallel plates, where $\left(L_{p} \gg e_{\mathrm{mac}}\right)$, is given by the equation of Poiseuille:

$$
\frac{d h}{d t}=\frac{e_{\mathrm{mac}}^{2} \Delta P}{12 \eta h},
$$

where $\Delta P=\Delta P_{c}-\rho g h ; \Delta P_{c}$ is the difference in pressure related to the capillary forces (law of Laplace). In the case of two parallel plates with $e_{\text {mac }}$ distance (as in two yarns) the Laplace law is

$$
\Delta P_{c}=\frac{2 \gamma_{L} \cos \theta}{e_{\mathrm{mac}}} .
$$

Thus the rate of change of height of liquid in macrocapillary is

$$
\frac{d h}{d t}=\frac{\left(e_{\mathrm{mac}} / \tau\right)^{2}}{12 \eta h}\left(\frac{2 \gamma_{L} \cos \theta}{e_{\mathrm{mac}}}-\rho g h\right),
$$

where $d h / d t$ is the rate of change of capillary height with respect to time, $e_{\mathrm{mac}}$ is the macrocapillary radius, $\tau$ is the tortuosity, $\eta$ is liquid viscosity, $h$ is the capillary height, $\gamma_{L}$ is surface tension, $\cos \theta$ is the contact angle of water with the fibre, $\rho$ is liquid density, and $g$ is acceleration due to gravity.

At equilibrium, the rate of change of height with respect to time is zero. That is, $d h / d t=0$. Putting this value in (7), we get

$$
h_{\mathrm{mac}-\mathrm{eq}}=\frac{2 \gamma_{L} \cos \theta}{e_{\mathrm{mac}} \rho g} .
$$

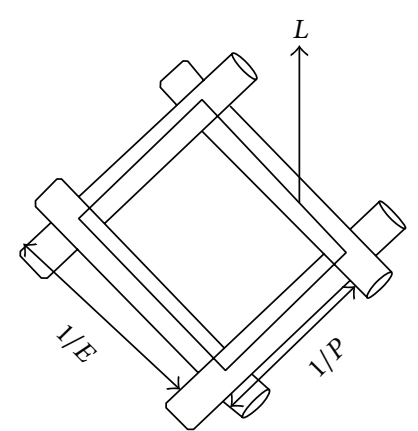

FIGURE 4: $L$ in unit cell of plain weave.

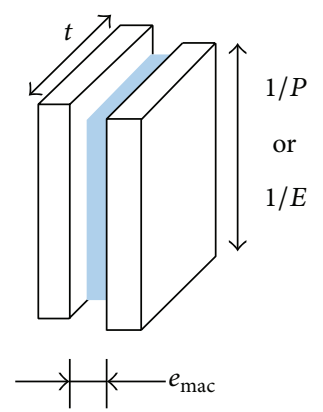

Figure 5: Parallelepiped.

From (7), (9) can be obtained for further evaluation of kinetics of capillary rise as follows:

$$
h=\frac{2 \gamma_{L} \cos \theta}{e_{\mathrm{mac}} \rho g}\left(1-\frac{1}{e^{\left(t t_{\mathrm{mac}}^{2} \rho g / \tau^{2} 12 \eta\right)}}\right) .
$$

Macrocapillary radius $\left(e_{\mathrm{mac}}\right)$ can be calculated as

Vacuum volume $=$ Total volume - Yarn volume

$$
\begin{gathered}
\text { Total volume }=\frac{t}{E \times P} \\
\text { Yarn volume }=\frac{\pi d_{\text {yarn }}^{2} L}{4},
\end{gathered}
$$

where $L$ is the length of yarn making one unit cell of plain weave (Figure 4).

Hence,

$$
\text { Vacuum volume }=\frac{t}{E \times P}-\frac{\pi d_{\text {yarn }}^{2} L}{4} .
$$

The capillary rise between yarns (on fabric scale) can be regarded as equivalent to a flow between two distant parallel plates of capillary distance $e_{\mathrm{mac}}$. The vacuum volume is equivalent to a parallelepiped volume having lengths $1 / P$ (if it is warp way capillary) and $1 / E$ (if it is weft way capillary), width $e_{\mathrm{mac}}$, and thickness $t$ (Figure 5):

parallelepiped volume $=\frac{t \times e_{\text {mac warp }}}{P}($ warp way capillary $)$, parallelepiped volume $=\frac{t \times e_{\mathrm{mac} w e f t}}{E}($ weft way capillary $)$. 


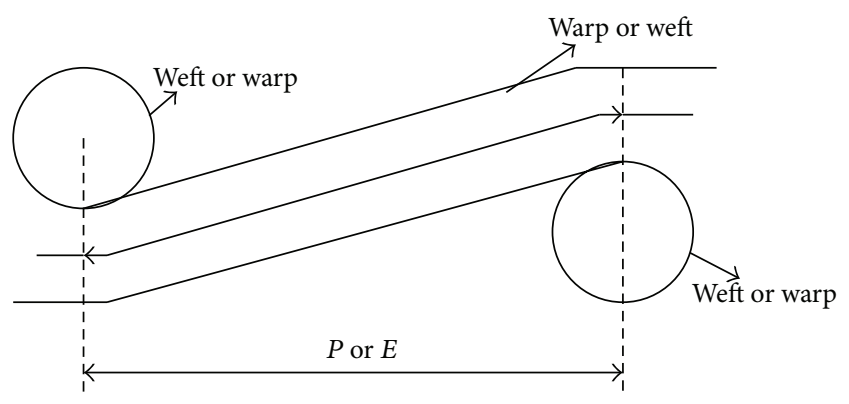

FIgURE 6: Geometry of the unit cell for a plain weave.

TABLE 2: Characteristics of distilled water at $20^{\circ} \mathrm{C}$.

\begin{tabular}{lc}
\hline Parameters & Value \\
\hline Density & $998.29 \mathrm{~kg} / \mathrm{m}^{3}$ \\
Dynamic viscosity & $0.001003 \mathrm{Kg} / \mathrm{m} \cdot \mathrm{s}$ \\
Surface energy & $72.5 \mathrm{~mJ} / \mathrm{m}^{2}$ \\
Contact angle/polyester fibre & $75^{\circ}$ \\
\hline
\end{tabular}

Using (13) and (14), the macrocapillary radius is

$$
\begin{aligned}
e_{\text {mac warp }} & =\frac{1}{E}-\frac{\pi d_{\text {yarn }}^{2} L P}{4 \times t} \text { (warp way capillary) }, \\
e_{\text {mac weft }} & =\frac{1}{P}-\frac{\pi d_{\text {yarn }}^{2} L E}{4 \times t} \text { (weft way capillary) } .
\end{aligned}
$$

Tortuosity. The tortuosity illustrated in Figure 6 is defined as

$$
\tau=\frac{L}{P \text { or } E},
$$

where $\tau$ is the tortuosity, $P$ and $E$ denote picks per inch and ends per inch, respectively, and $L$ is given by

$$
L=(1+C) \times(P \text { or } E) .
$$

Here $C$ denotes the crimp (it is measure of waviness in yarns) which can be calculated by taking out the yarns from the fabric and measuring crimp condition length and then applying force from both ends of the yarn and measuring the actual length after application of force [23].

Consider

$$
C=\frac{\text { Actual length }- \text { Crimp condition length }}{\text { Crimp condition length }} \text {. }
$$

From equations (16), (17), and (18) we get

$$
\tau=(1+C) \text {. }
$$

2.2.3. Liquid Characteristics. The characteristics of liquid used for carrying out wicking test are given in Table 2.

\section{Results and Discussions}

3.1. Experimental and Theoretical Vertical Wicking of Polyester. Figures 7 to 14 show the results of experimental and theoretical vertical wicking of polyester both warp and weft

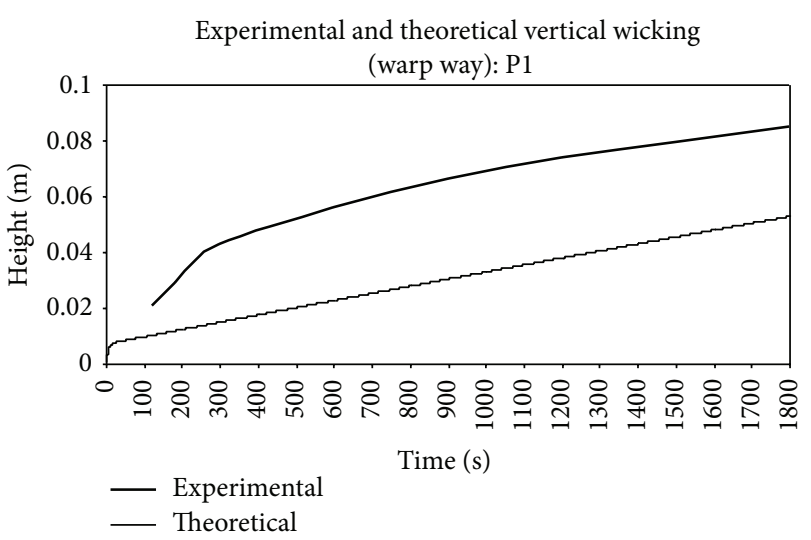

(a)

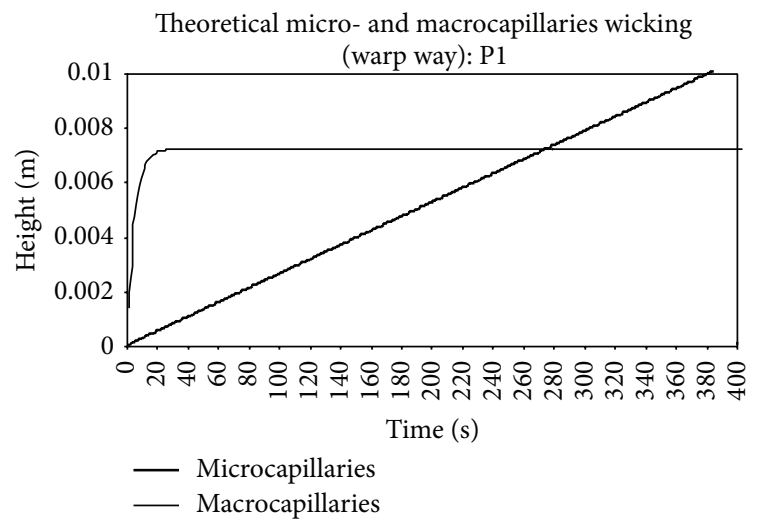

(b)

Figure 7: (a) Experimental and theoretical vertical wicking. (b) Theoretical micro- and macrocapillaries wicking (warp way, P1).

ways and the theoretical vertical wicking in micro- and macrocapillaries. It is seen from the figures that the maximum height reached in 1800 seconds experimentally for all the samples of polyester in both warp and weft ways is more than that of the theoretical values.

When the fabric strip is dipped in liquid reservoir, the smaller capillaries are filled first because of higher capillary pressure followed by larger capillaries. The mass of liquid retained in small capillaries is less as compared to large capillaries. Due to less capillary pressure in large capillaries the liquid advancement is less but the liquid retained by these capillaries acts as reservoir for small capillaries. Liquid reservoir is also present at the points where yarns are intersecting. So for wicking to take place, liquid placed at the bottom of fabric strip is the main reservoir; the liquid retained in large capillaries and at the intersection points of yarns act as mini reservoirs.

In theoretical calculation, it was assumed that the capillaries are uniform. But in actual fabric capillaries are not uniform or continuous between fibres and yarns. It may be assumed that in fabric a large number of small capillaries are joined by large number of mini reservoirs which act as source of liquid for these small capillaries. With time and gradual rise of liquid, the amount of liquid available in the 


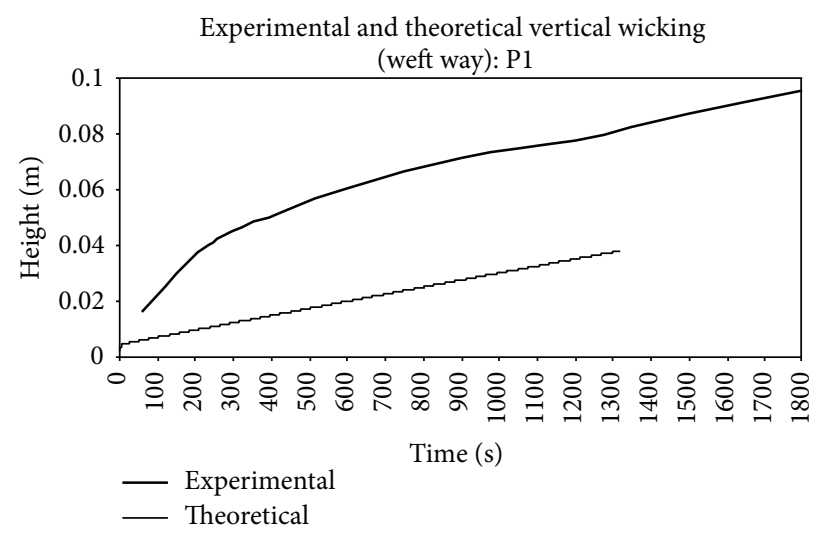

(a)

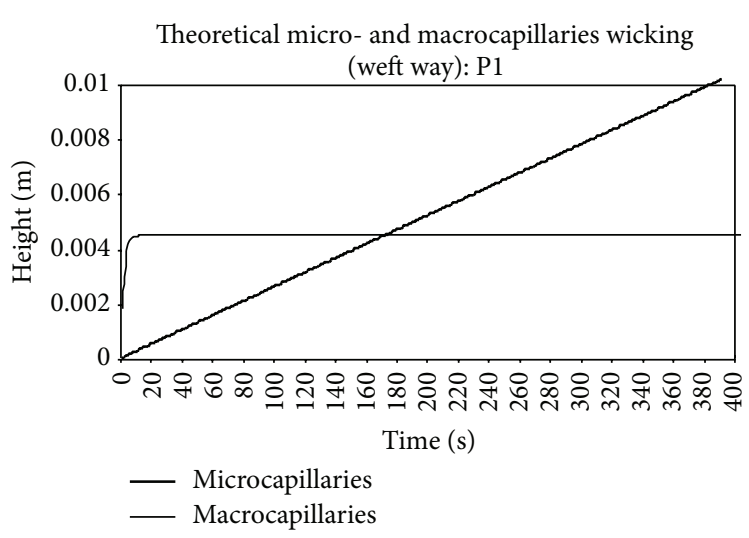

(b)

FIgURE 8: (a) Experimental and theoretical vertical wicking. (b) Theoretical micro- and macrocapillaries wicking (weft way, P1).

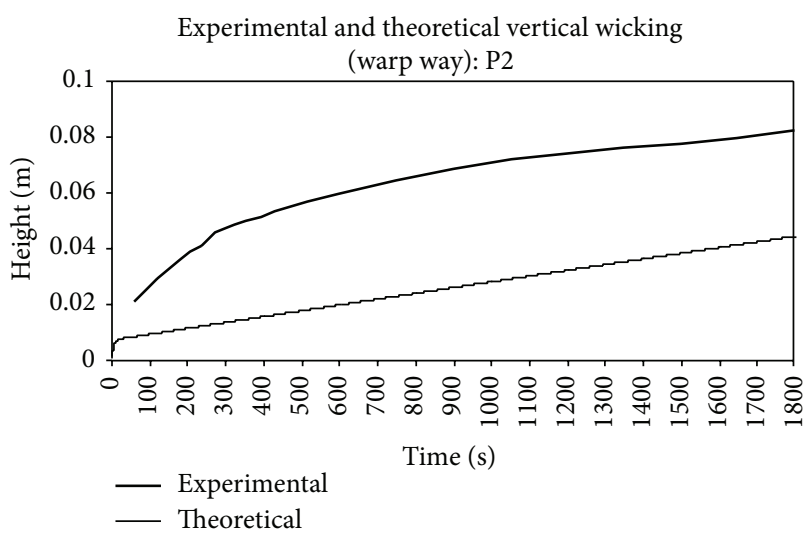

(a)

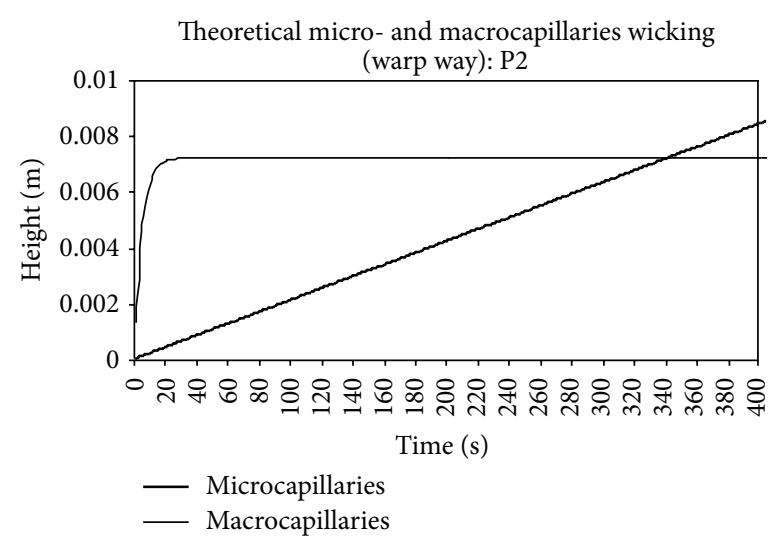

(b)

FIGURE 9: (a) Experimental and theoretical vertical wicking. (b) Theoretical micro- and macrocapillaries wicking (warp way, P2).

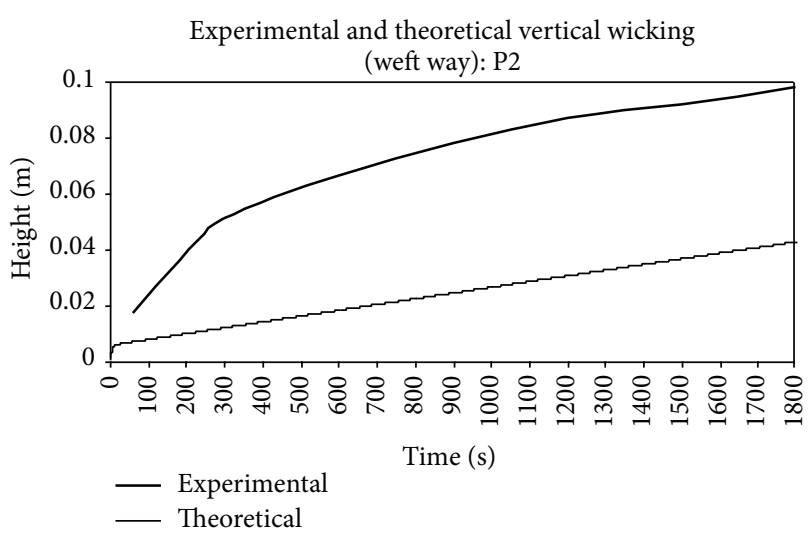

(a)

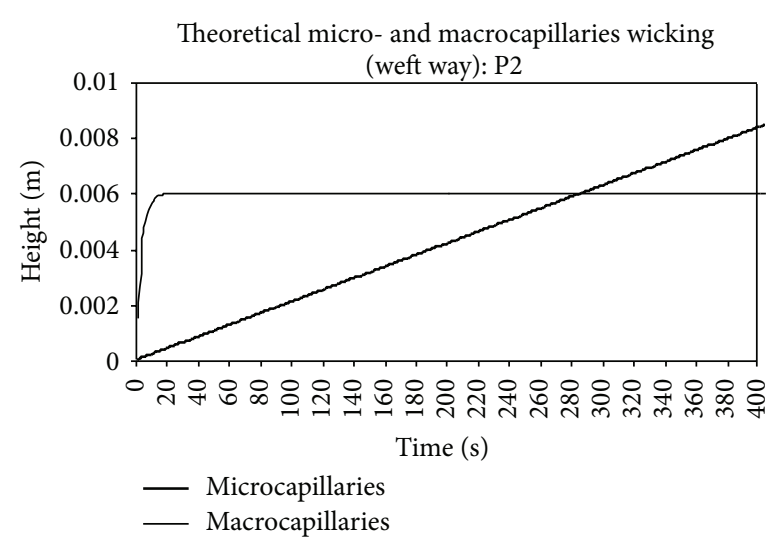

(b)

FIGURE 10: (a) Experimental and theoretical vertical wicking. (b) Theoretical micro- and macrocapillaries wicking (weft way, P2).

subsequent mini reservoirs keeps decreasing and when the pressure difference between the small capillaries and mini reservoirs ceases to exist, the equilibrium is achieved. Because of this reason, the experimental values are higher than the corresponding theoretical values.
3.2. Effect of Sample Direction for Vertical Wicking of Polyester. Samples are cut in warp way and weft way directions for vertical wicking test. Theoretical values are based on certain variables; change in those variables brings about change in maximum height reached in warp way and weft way 


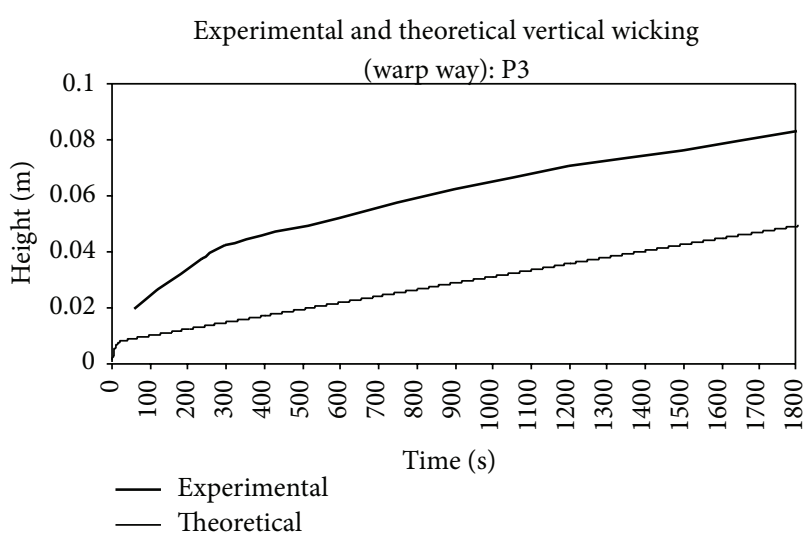

(a)

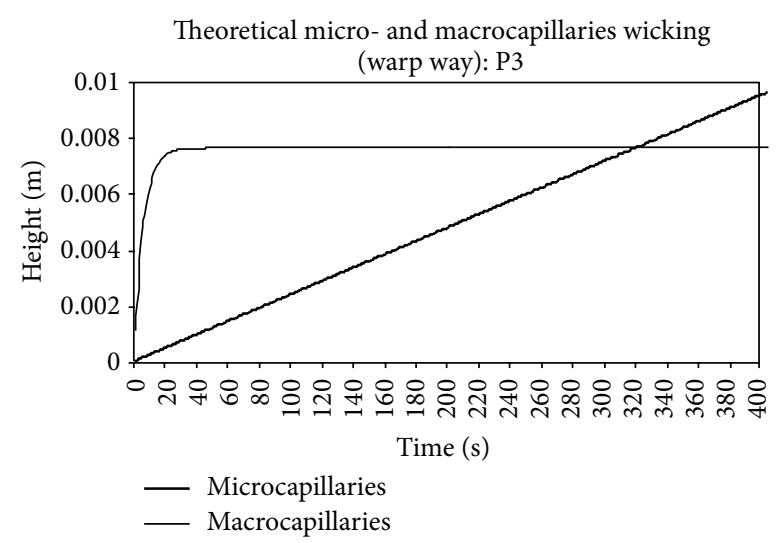

(b)

FIGURE 11: (a) Experimental and theoretical vertical wicking. (b) Theoretical micro- and macrocapillaries wicking (warp way, P3).

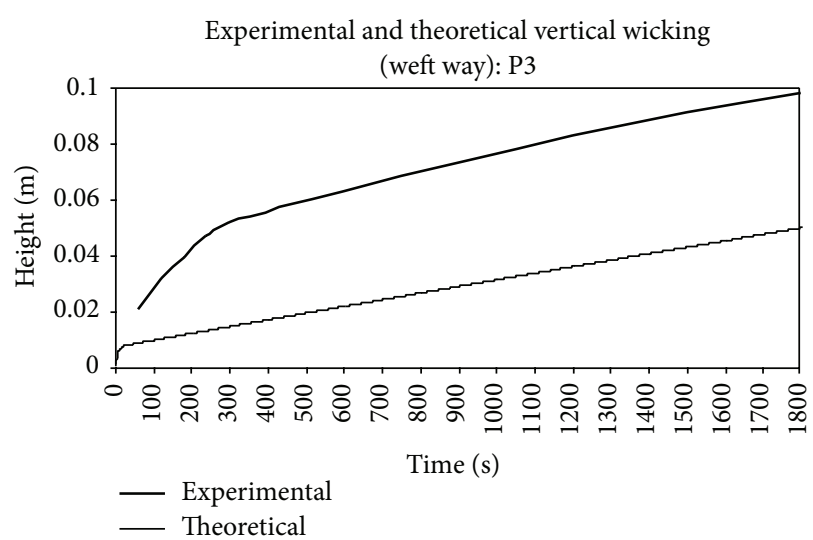

(a)

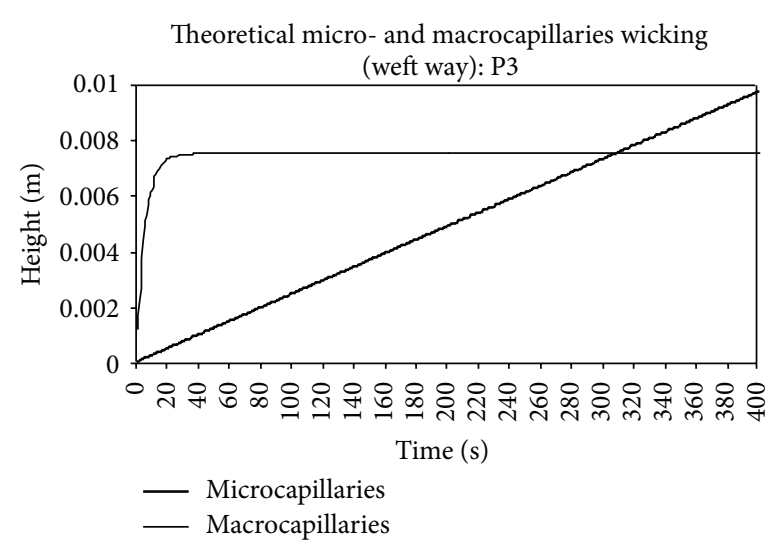

(b)

FIGURE 12: (a) Experimental and theoretical vertical wicking. (b) Theoretical micro- and macrocapillaries wicking (weft way, P3).

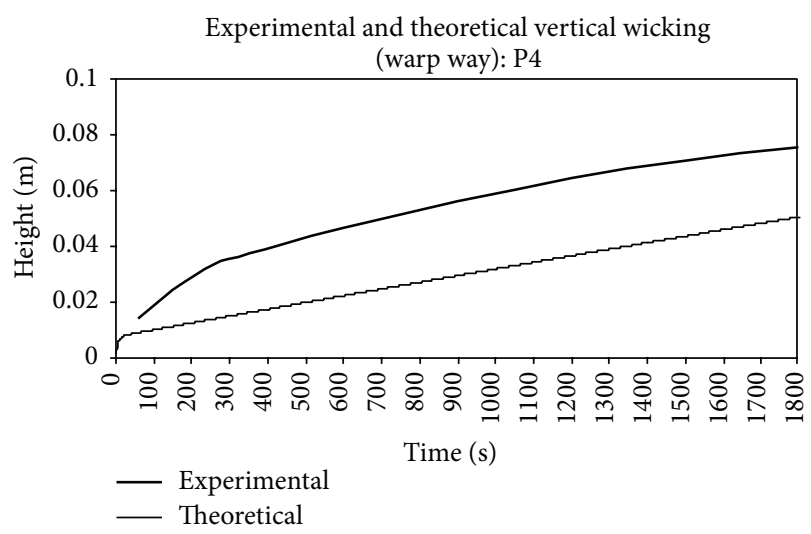

(a)

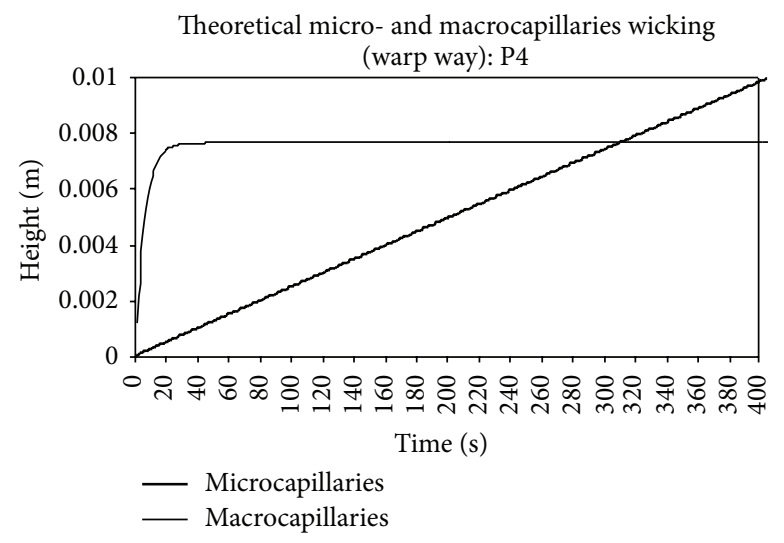

(b)

FIgURE 13: (a) Experimental and theoretical vertical wicking. (b) Theoretical micro- and macrocapillaries wicking (warp way, P4).

directions. From Table 3 it can be observed that for P1 and P2 fabric warp way wicking height is more as that of weft way wicking height but for $\mathrm{P} 3$ and $\mathrm{P} 4$ fabric the situation is reversed.
But for the experimental values for maximum height reached, it is observed that the maximum height reached in weft way is more as compared to maximum height reached in warp way in all cases of polyester samples (Table 3 ). 


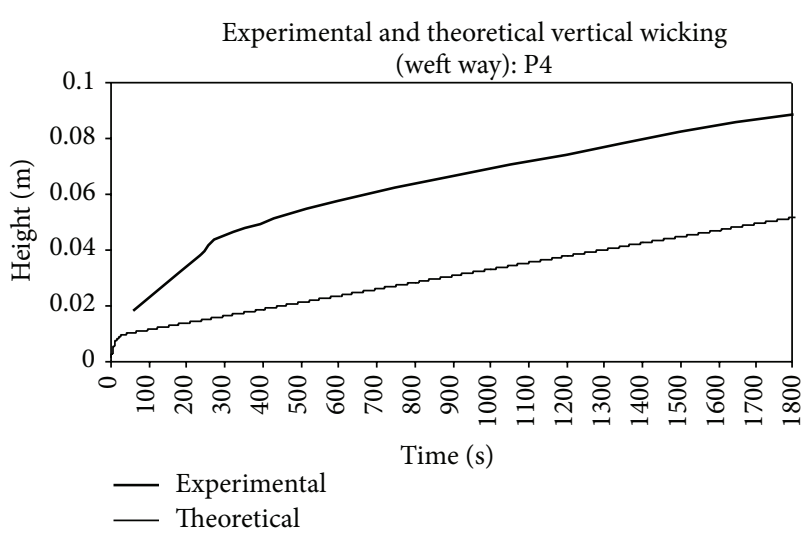

(a)

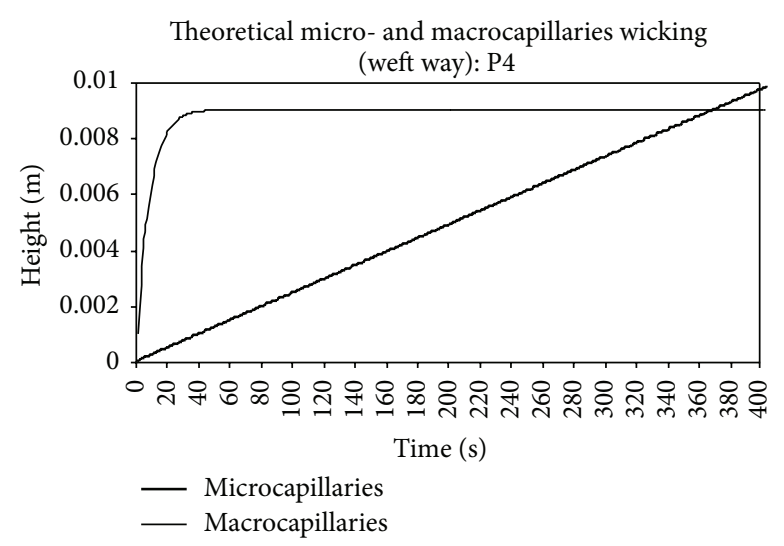

(b)

FIGURE 14: (a) Experimental and theoretical vertical wicking. (b) Theoretical micro- and macrocapillaries wicking (weft way, P4).

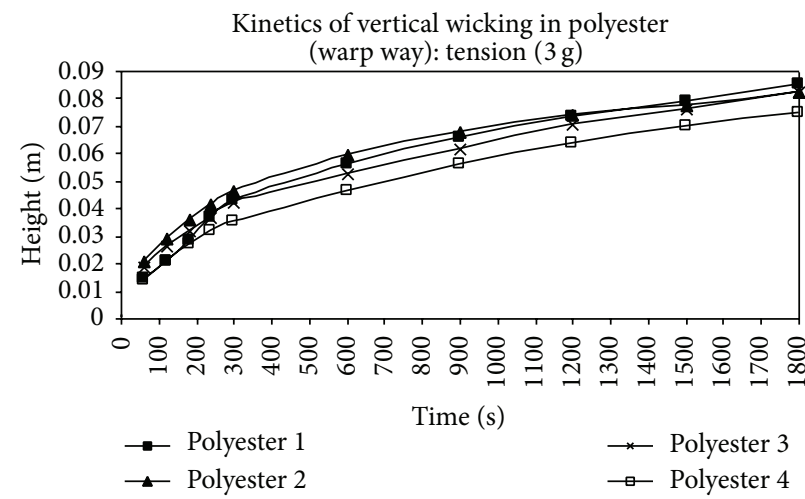

(a)

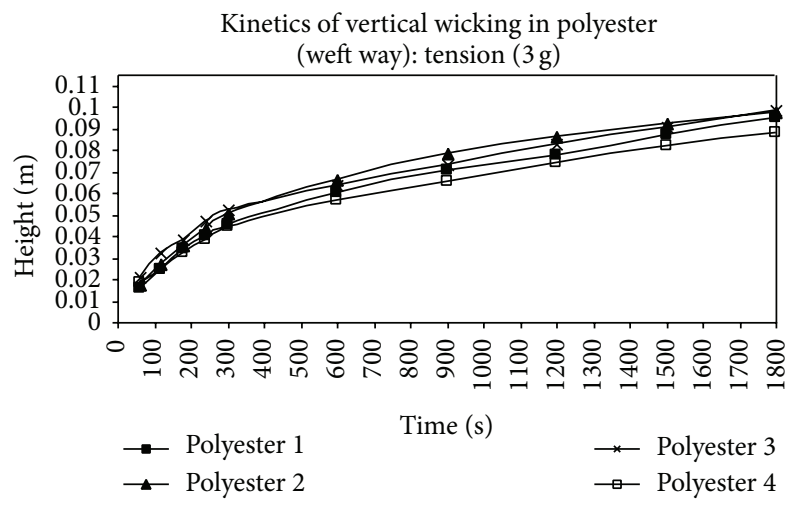

(b)

FIGURE 15: Kinetics of vertical wicking in polyester at $3 \mathrm{~g}$, (a) warp way and (b) weft way.

Though the same yarn was used both as warp and as weft, a difference in warp way wicking and weft way wicking behaviour suggests that there has to be some difference in terms of size and distribution of capillaries in the respective directions. The difference in tension of warp and weft yarn during fabric formation may be responsible for difference in size and disposition of capillaries in two directions. Warp yarns, being in more stressed condition than weft yarns, have a more compact structure due to which the radius of the values of micro- and macrocapillaries formed will be less. This will slow down the rate of capillary rise and in a given time the height reached will be less. It is also evident from the experimental vertical wicking graphs (Figures 7, 8, 9, 10, 11, 12,13 , and 14) that the initial rate of wicking is greater in weft way than in warp way which supports the difference in size and disposition of capillary in warp way and weft way.

It may also be mentioned here that within the range investigated, irrespective of the ends per inch and picks per inch, the weft way wicking is more than that of the warp way wicking.

3.3. Effect of Change in Pick Density. As pick density increases, wicking height decreases. Figures 15, 16, 17, and 18 show the relation between pick density and wicking height. The results obtained are significant at 95\% level. Theoretical calculation of effect of pick density on wicking height is also in line with experimental results and may be explained as follows.

(i) With increase in pick density fabric structure is becoming more compact, due to which thickness is increasing gradually which is influencing the microcapillary radius. Theoretically according to (4), thickness $(t)$, number of fibres in yarn $\left(n_{s}\right)$ and fibre diameter $(d)$ can bring a change in micro capillary radius $\left(R_{\mathrm{mi}}\right)$. In this case thickness is the only variable and the other two factors are constant. So higher thickness value will give higher microcapillary radius. So, as pick density is increased micro capillary radius will increase (Table 1) and due to which capillary pressure will decrease which is responsible for wicking; the less the capillary pressure is, the less the wicking will be. Because of this theoretical reason, wicking height is reduced as pick density is increased. Theoretically, (15), change in pick density and thickness of fabric will affect the macrocapillary radius. With increase in pick density and thickness, the macrocapillary radius will 


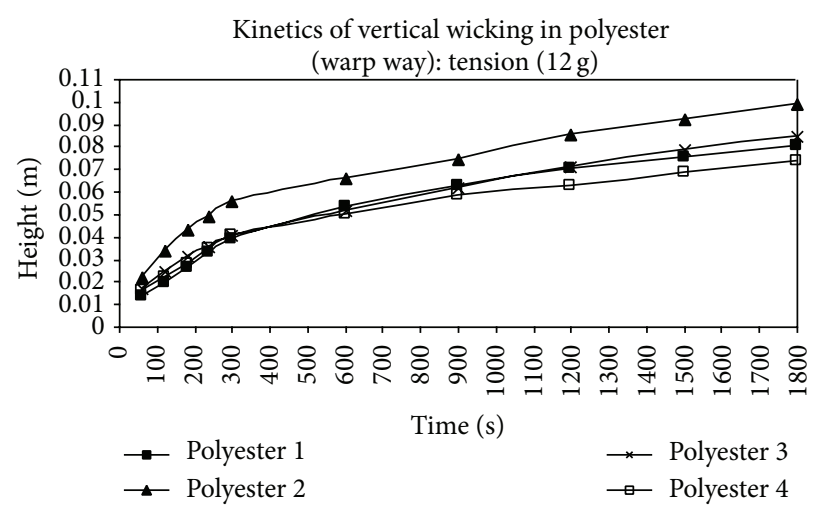

(a)

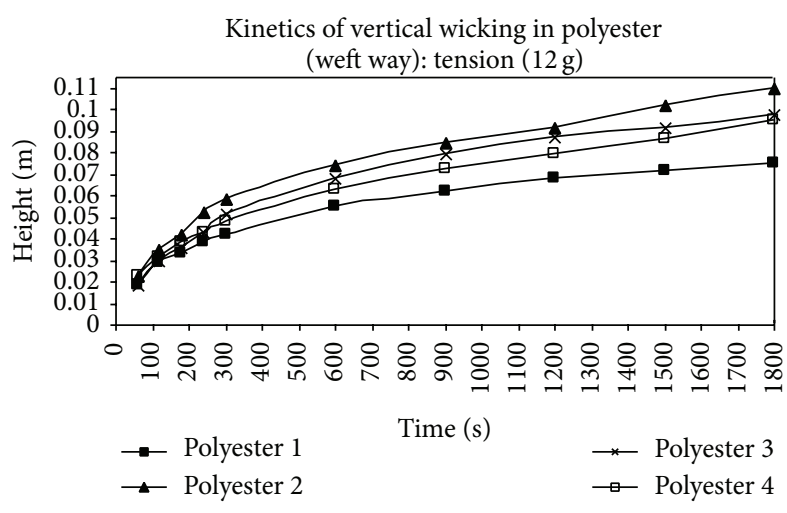

(b)

FIGURE 16: Kinetics of vertical wicking in polyester at $12 \mathrm{~g}$, (a) warp way and (b) weft way.

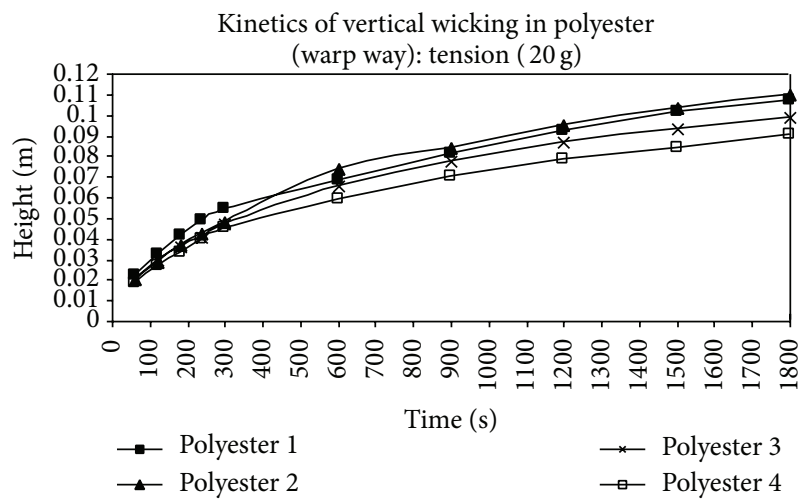

(a)

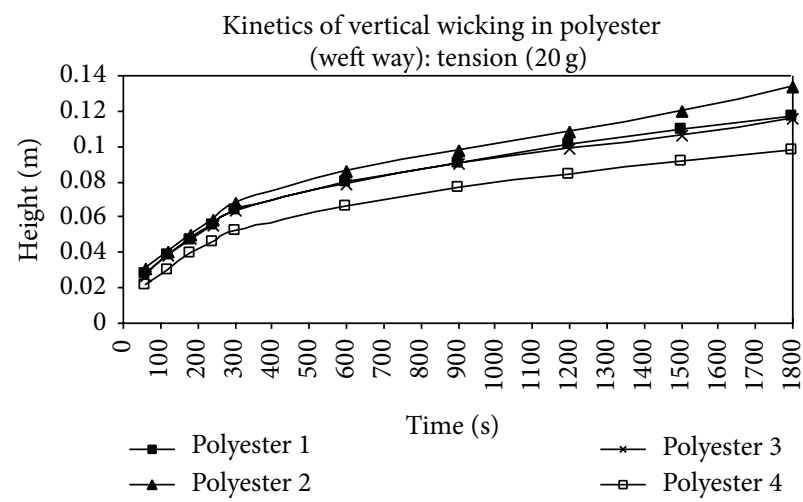

(b)

FIGURE 17: Kinetics of vertical wicking in polyester at $20 \mathrm{~g}$, (a) warp way and (b) weft way.

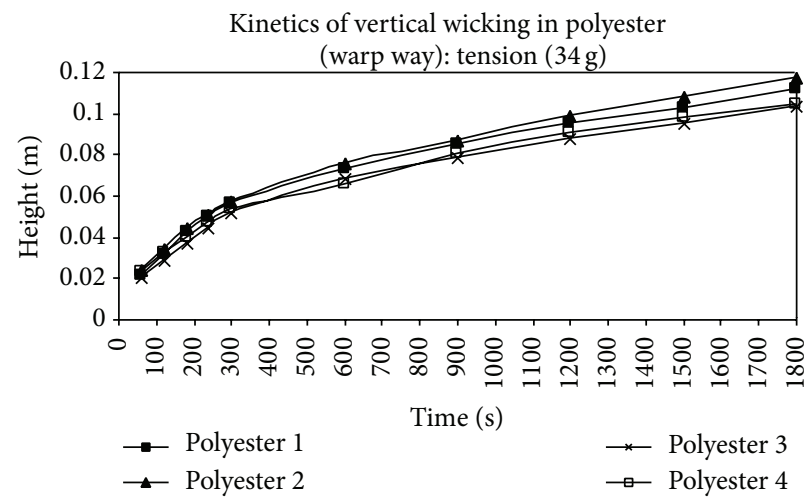

(a)

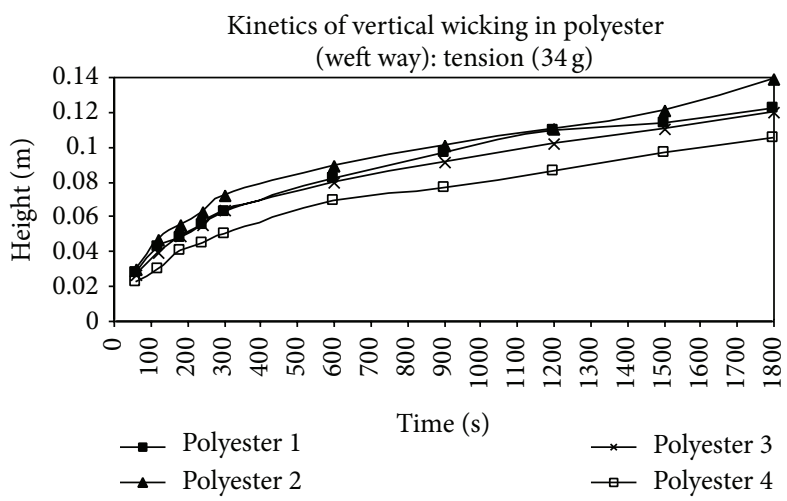

(b)

FIGURE 18: Kinetics of vertical wicking in polyester at $34 \mathrm{~g}$, (a) warp way and (b) weft way.

decrease (Table 4). Macrocapillaries are responsible for short term wicking less will be the capillary radius less would be the initial rate and hence less wicking height. Moreover, the liquid which is retained in these capillaries will decrease. Liquid retained in capillaries acts as reservoir and helps in increasing the wicking height. Due to this reason as we move on to higher pick density the wicking height is reduced. (ii) With change in pick density crimp in yarn will change. The more the pick density is, the more the crimp will be there in yarn and the more the tortuosity will be (19). With an increase in the tortuosity of the capillaries, its wicking potential is reduced.

Fabric with pick density 30 does not follow the abovementioned trend. This may be due to the fact that in this fabric 


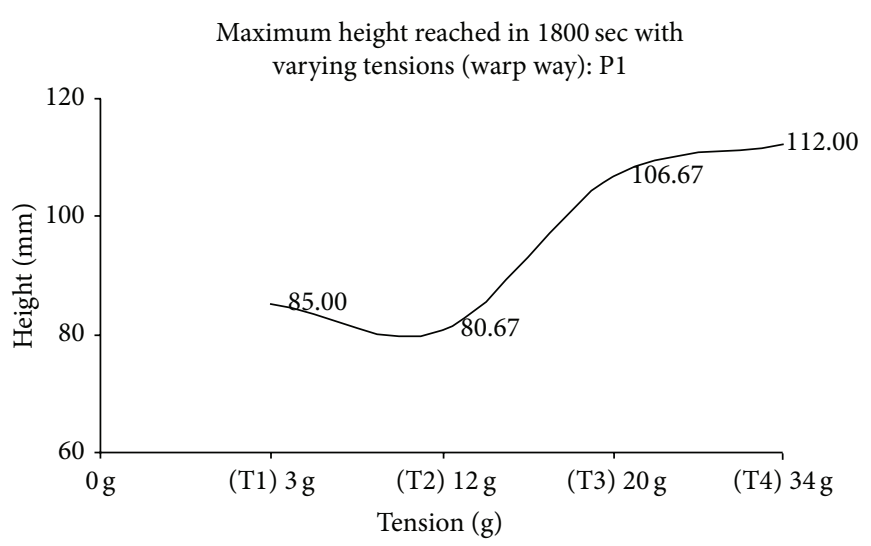

(a)

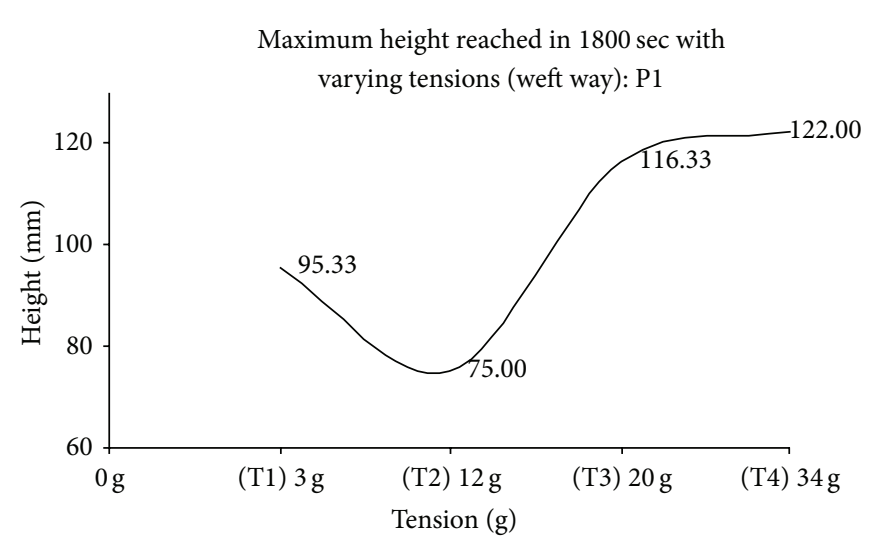

(b)

FIGURE 19: Maximum height reached with varying tension, (a) warp way and (b) weft way (P1).

TABLE 3: Maximum height reached in 1800 seconds (polyester).

\begin{tabular}{lcccc}
\hline & P1 & P2 & P3 & P4 \\
\hline $\begin{array}{l}\text { Theoretical values warp } \\
\text { way (m) }\end{array}$ & 0.053 & 0.044 & 0.049 & 0.051 \\
$\begin{array}{l}\text { Theoretical values weft } \\
\text { way (m) }\end{array}$ & 0.050 & 0.043 & 0.050 & 0.052 \\
$\begin{array}{l}\text { Experimental values warp } \\
\text { way (m) }\end{array}$ & 0.085 & 0.082 & 0.083 & 0.075 \\
$\begin{array}{l}\text { Experimental values weft } \\
\text { way (m) }\end{array}$ & 0.095 & 0.098 & 0.098 & 0.088 \\
\hline
\end{tabular}

TABLE 4: Micro- and macrocapillary radius (polyester).

\begin{tabular}{lccc}
\hline & P2 & P3 & P4 \\
\hline $\begin{array}{l}\text { Microcapillary } \\
\text { radius } R_{\text {mi }}(\mathrm{m})\end{array}$ & $5.037 E-6$ & $6.247 E-6$ & $6.359 E-6$ \\
$\begin{array}{l}\text { Warp macrocapillary } \\
\text { radius } e_{\text {mac warp }}(\mathrm{m})\end{array}$ & $5.292 E-4$ & $5.000 E-4$ & $5.000 E-4$ \\
$\begin{array}{l}\text { Weft macrocapillary } \\
\text { radius } e_{\text {mac weft }}(\mathrm{m})\end{array}$ & $6.350 E-4$ & $5.080 E-4$ & $4.230 E-4$ \\
\hline
\end{tabular}

TABLE 5: Thickness of polyester fabrics.

\begin{tabular}{lcccc}
\hline & P1 & P2 & P3 & P4 \\
\hline $\begin{array}{l}\text { Experimental thickness } \\
(\mathrm{m})\end{array}$ & 0.000535 & 0.000493 & 0.000544 & 0.000549 \\
$\begin{array}{l}\text { Theoretical thickness } \\
(\mathrm{m})\end{array}$ & 0.000526 & 0.000508 & 0.00053 & 0.000486 \\
\hline
\end{tabular}

the stress generated at yarn intersection point is less due to smaller number of picks per inch and because of this the structure of yarns is closer to cylindrical structure. This assumption is also supported by the measured thickness values of the fabric and theoretical value of thickness which is calculated based on Pierce's Geometry (Table 5). The thickness of the fabric P1 is close to that of the fabric P3 both experimentally and theoretically.
In actual experiment the change in wicking height with variation in pick density may be attributed to the effect of the above-mentioned factors either individually or collectively.

3.4. Effect of Change in Tension on Polyester. Wicking height increases with increase in tension in P2, P3, and P4 fabrics (Figure 15). Due to presence of twist in yarn, when tension was applied on fabric, the fibres inside the yarn will become compact (due to lateral pressure developed) and hence more parallel along yarn axis. Because of this dimension of microcapillary radius is decreasing, so when strip with tension attached at bottom is immersed in water liquid will wick in these small capillaries formed because of higher capillary pressure developed since capillary pressure is inversely related to micro capillary radius.

At higher tension, dimensional change in capillaries is negligible as is observed in Figures 19, 20, 21, and 22 that from $20 \mathrm{~g}$ tension to $34 \mathrm{~g}$ tension. As at higher tension or after critical tension micro and macro capillaries available for wicking to take place are becoming constant.

Behaviour of $\mathrm{P} 1$ fabric with increase in tension is different from other fabrics. In Figure 22 maximum wicking height at $12 \mathrm{~g}$ tension is less than $3 \mathrm{~g}$. As $3 \mathrm{~g}$ load is less to bring any change in arrangement of fibres inside yarn and in yarn itself. Due to smaller number of yarns in warp (EPI 48), and weft (PPI 30) way, structure of yarn in fabric is more similar to cylindrical structure. And when tension is increased to $12 \mathrm{~g}$ the cylindrical structure becomes flat due to application of load; hence, micro- and macrocapillaries that existed are distributed and may lead to increase in capillary radius due to which less wicking is observed in this fabric at $12 \mathrm{~g}$ tension. From $12 \mathrm{~g}$ to $20 \mathrm{~g}$ and $34 \mathrm{~g}$ this fabric is behaving in the same way as that of $\mathrm{P} 2, \mathrm{P} 3$, and $\mathrm{P} 4$.

\section{Conclusions}

Wicking takes place through microcapillaries and macrocapillaries in fabric. It is difficult to analyse the interconnection between micro- and macrocapillaries, so kinetics for microcapillary and macrocapillary was studied at different wicking 


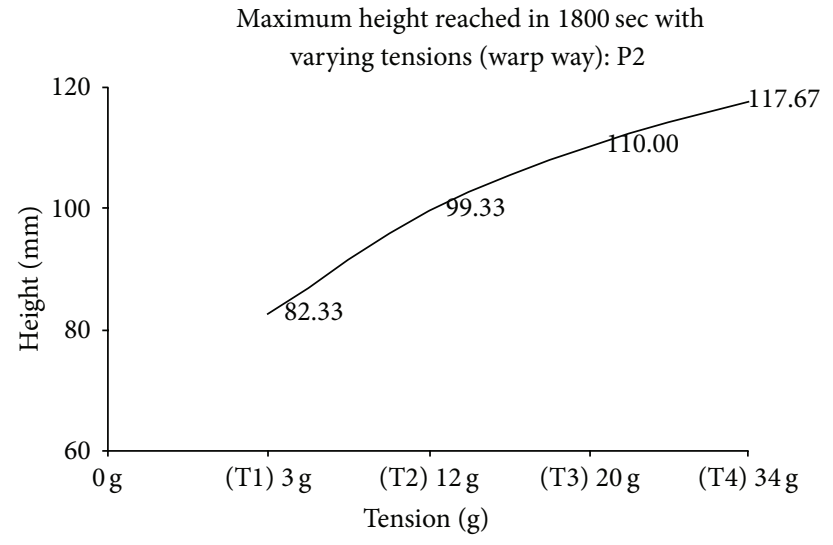

(a)

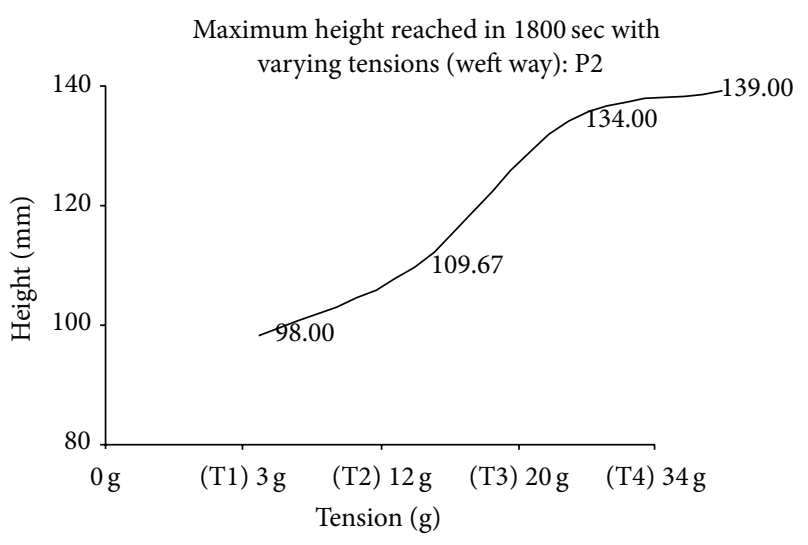

(b)

FIGURE 20: Maximum height reached with varying tension, (a) warp way and (b) weft (P2).

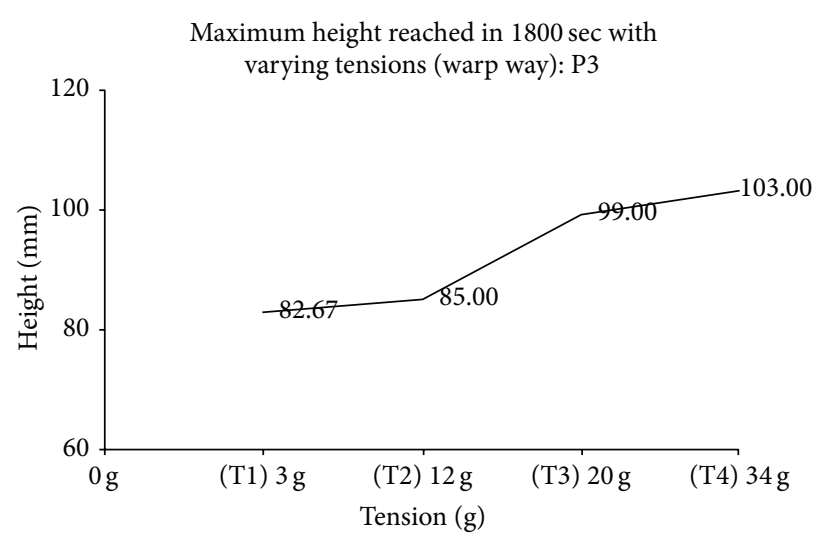

(a)

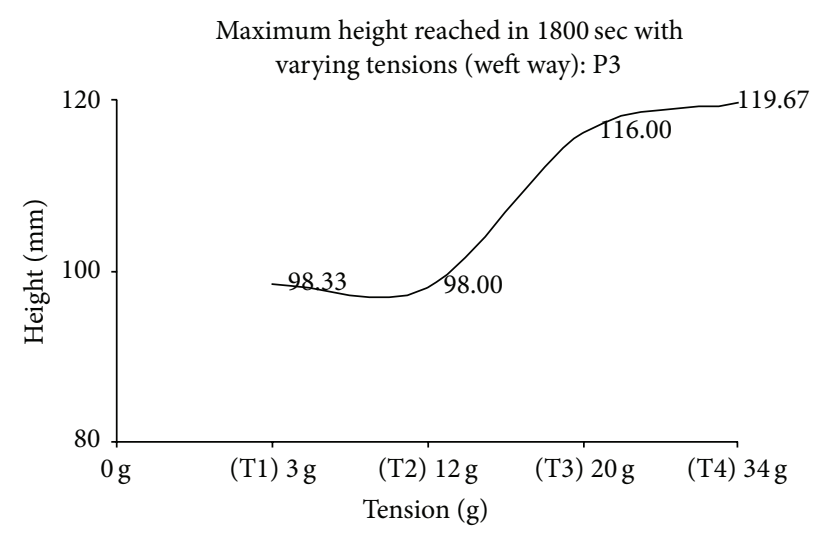

(b)

FIGURE 21: Maximum height reached with varying tension, (a) warp way and (b) weft way (P3).

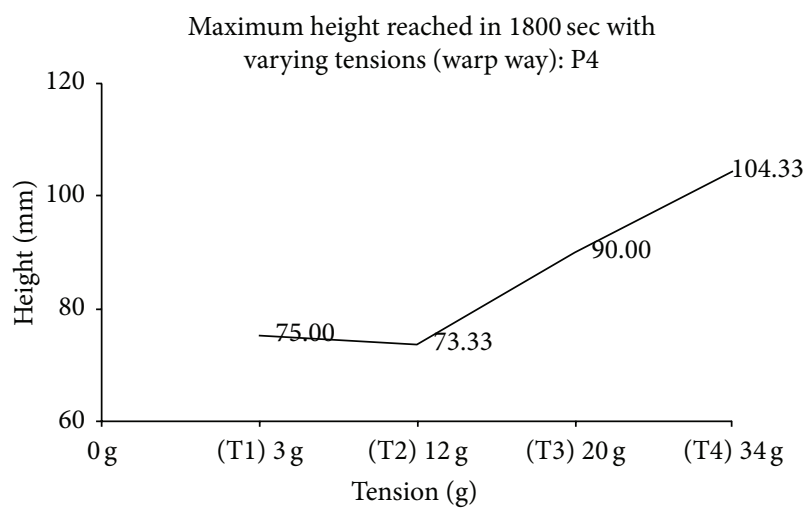

(a)

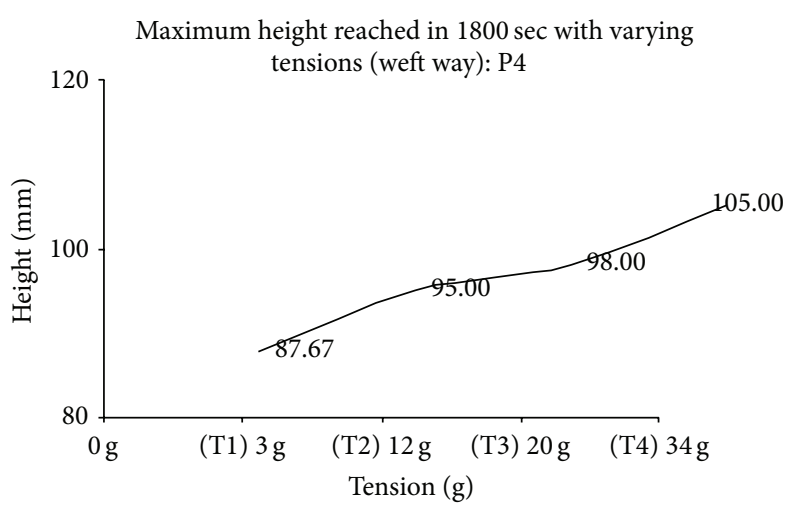

(b)

FIgURE 22: Maximum height reached with varying tension, (a) warp way and (b) weft way (P4). 
moments by using Lucas-Washburn equation. Macrocapillaries are responsible for short term wicking and microcapillaries are responsible for long term wicking reaching maximum height with slow diffusion rate. Tension influences the results of the wicking test. With increase in tension wicking height increases and after a critical tension no further change is observed. Actual structure of textile is more complex than an idealized assembly of cylinder, so exact prediction is difficult. Further refinement of the equations is necessary.

\section{Conflict of Interests}

The authors declare that there is no conflict of interests regarding the publication of this paper.

\section{References}

[1] B. V. Zhmud, F. Tiberg, and K. Hallstensson, "Dynamics of capillary rise," Journal of Colloid and Interface Science, vol. 228, no. 2, pp. 263-269, 2000.

[2] D. Knittel and E. Schollmeyer, "Notes on future developments for textile finishing processes," The Journal of The Textile Institute, vol. 91, part 3, pp. 166-167, 2000.

[3] E. Kissa, "Wetting and wicking," Textile Research Journal, vol. 66, no. 10, pp. 660-668, 1996.

[4] K. C. Parsons, Human Thermal Environments, Taylor \& Francis, London, UK, 1993.

[5] B. Das, A. Das, V. Kothari, R. Fanguiero, and M. D. Araujo, "Moisture flow through blended fabrics-effect of hydrophilicity," Journal of Engineered Fibers and Fabrics, vol. 4, no. 4, pp. 20-28, 2009.

[6] N. R. S. Hollies, M. M. Kaessinger, and H. Bogaty, "Water transport mechanisms in textile materials1-part I: the role of yarn roughness in capillary-type penetration," Textile Research Journal, vol. 26, pp. 829-835, 1956.

[7] N. R. S. Hollies, M. M. Kaessinger, B. S. Watson, and H. Bogaty, "Water transport mechanisms in textile materialspart II: capillary-type penetration in yarns and fabrics," Textile Research Journal, vol. 27, pp. 8-13, 1957.

[8] S. C. Amico and C. Lekakou, "Mathematical modelling of capillary micro-flow through woven fabrics," Composites A, vol. 31, no. 12, pp. 1331-1344, 2000.

[9] S. C. Amico and C. Lekakou, "Axial impregnation of a fiber bundle-part 1: capillary experiments," Polymer Composites, vol. 23, no. 2, pp. 249-263, 2002.

[10] S. C. Amico and C. Lekakou, "Axial impregnation of a fiber bundle-part 2: theoretical analysis," Polymer Composites, vol. 23, no. 2, pp. 264-273, 2002.

[11] P. K. Chatterjee, Absorbent Technology, Elsevier Scientific, New York, NY, USA, 1985.

[12] Y. K. Kamath, S. B. Hornby, H. D. Weigmann, and M. F. Wilde, "Wicking of spin finishes and related liquids into continuous filament yarns," Textile Research Journal, vol. 64, no. 1, pp. 3340, 1994.

[13] A. B. Nyoni and D. Brook, "Wicking mechanisms in yarnsthe key to fabric wicking performance," Journal of the Textile Institute, vol. 97, no. 2, pp. 119-128, 2006.

[14] A. Perwuelz, P. Mondon, and C. Caze, "Experimental study of capillary flow in yarns," Textile Research Journal, vol. 70, no. 4, pp. 333-339, 2000.
[15] A. Perwuelz, M. Casetta, and C. Caze, "Liquid organisation during capillary rise in yarns-influence of yarn torsion," Polymer Testing, vol. 20, no. 5, pp. 553-561, 2001.

[16] E. W. Washburn, “The dynamics of capillary flow," Physical Review, vol. 17, no. 3, pp. 273-283, 1921.

[17] T. Liu, K.-F. Choi, and Y. Li, "Wicking in twisted yarns," Journal of Colloid and Interface Science, vol. 318, no. 1, pp. 134-139, 2008.

[18] B. Sofien, F. Faten, and B. Sassi, "Capillary rise in macro and micro pores of jersey knitting structure," Journal of Engineered Fibres and Fabrics, vol. 3, no. 3, pp. 47-54, 2008.

[19] H. Ito and Y. Muraoka, "Water transport along textile fibers as measured by an electrical capacitance technique," Textile Research Journal, vol. 63, no. 7, pp. 414-420, 1993.

[20] S. S. Ramkumar, A. Purushothaman, K. D. Hake, and D. D. Mcalister III, "Relationship between cotton varieties and moisture vapor transport of knitted fabrics," Journal of Engineered Fibers and Fabrics, vol. 2, no. 4, 2007.

[21] S. Irandoukht and A. Irandoukht, "Development of the predictive models for the fabric water vapor resistance," Journal of Engineered Fibers and Fabrics, vol. 6, no. 2, pp. 40-49, 2011.

[22] S. Lee and S. K. Obendorf, "Statistical modeling of water vapor transport through woven fabrics," Textile Research Journal, vol. 82, no. 3, pp. 211-219, 2012.

[23] B. P. Saville, Physical Testing of Textiles, The Textile Institute, Woodhead, Cambridge, UK, 2000. 

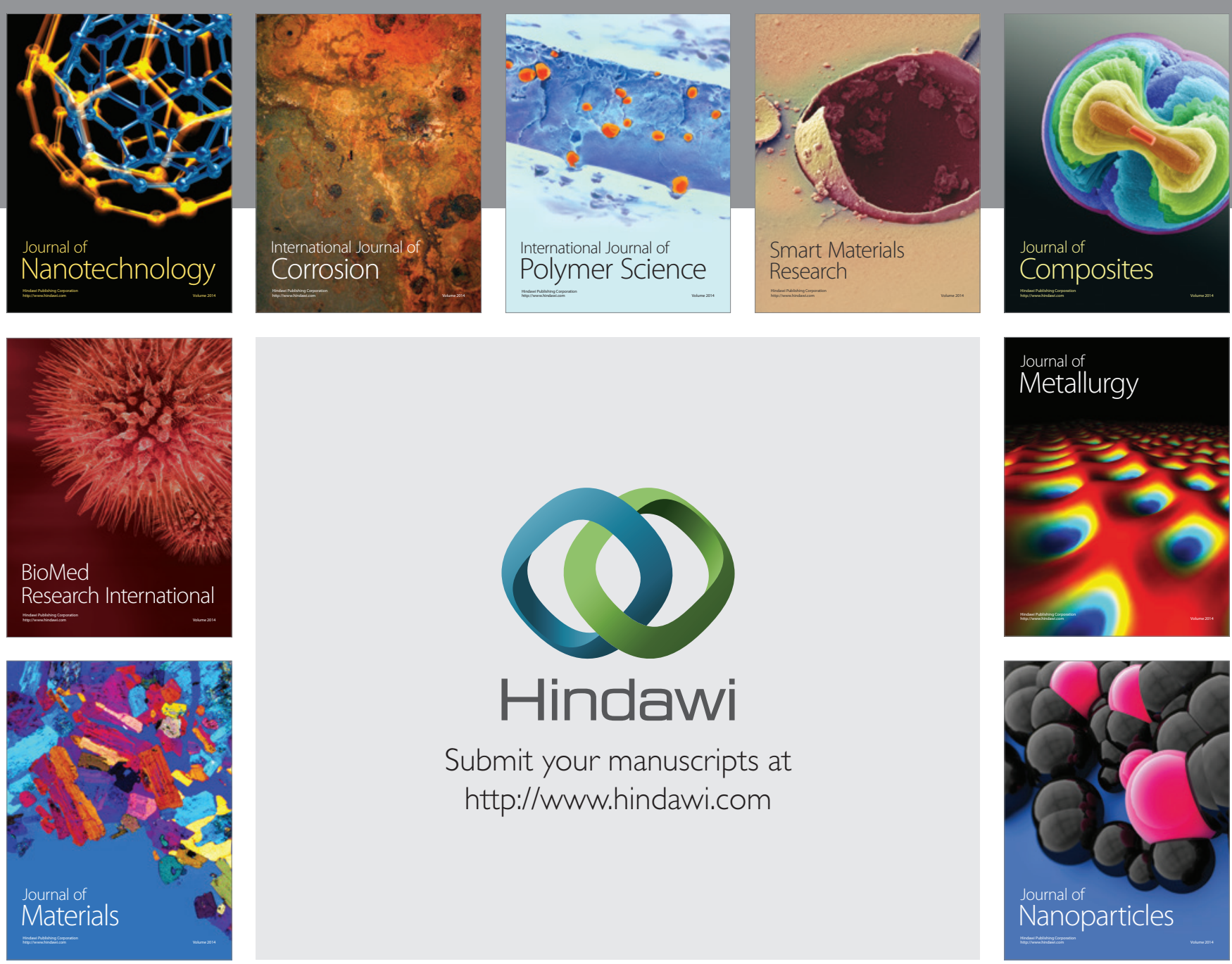

Submit your manuscripts at http://www.hindawi.com
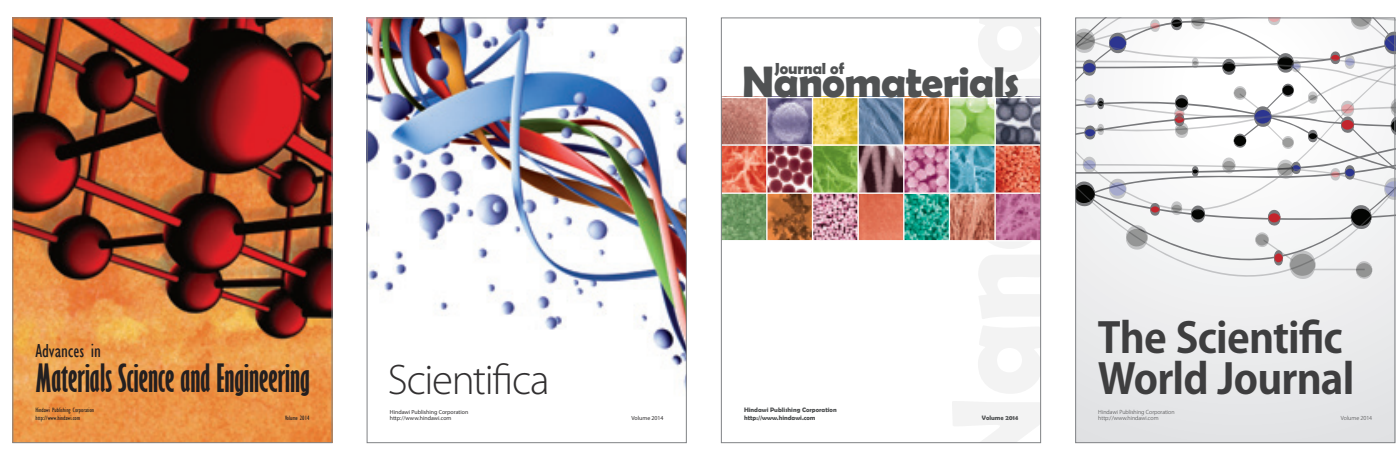

\section{The Scientific World Journal}
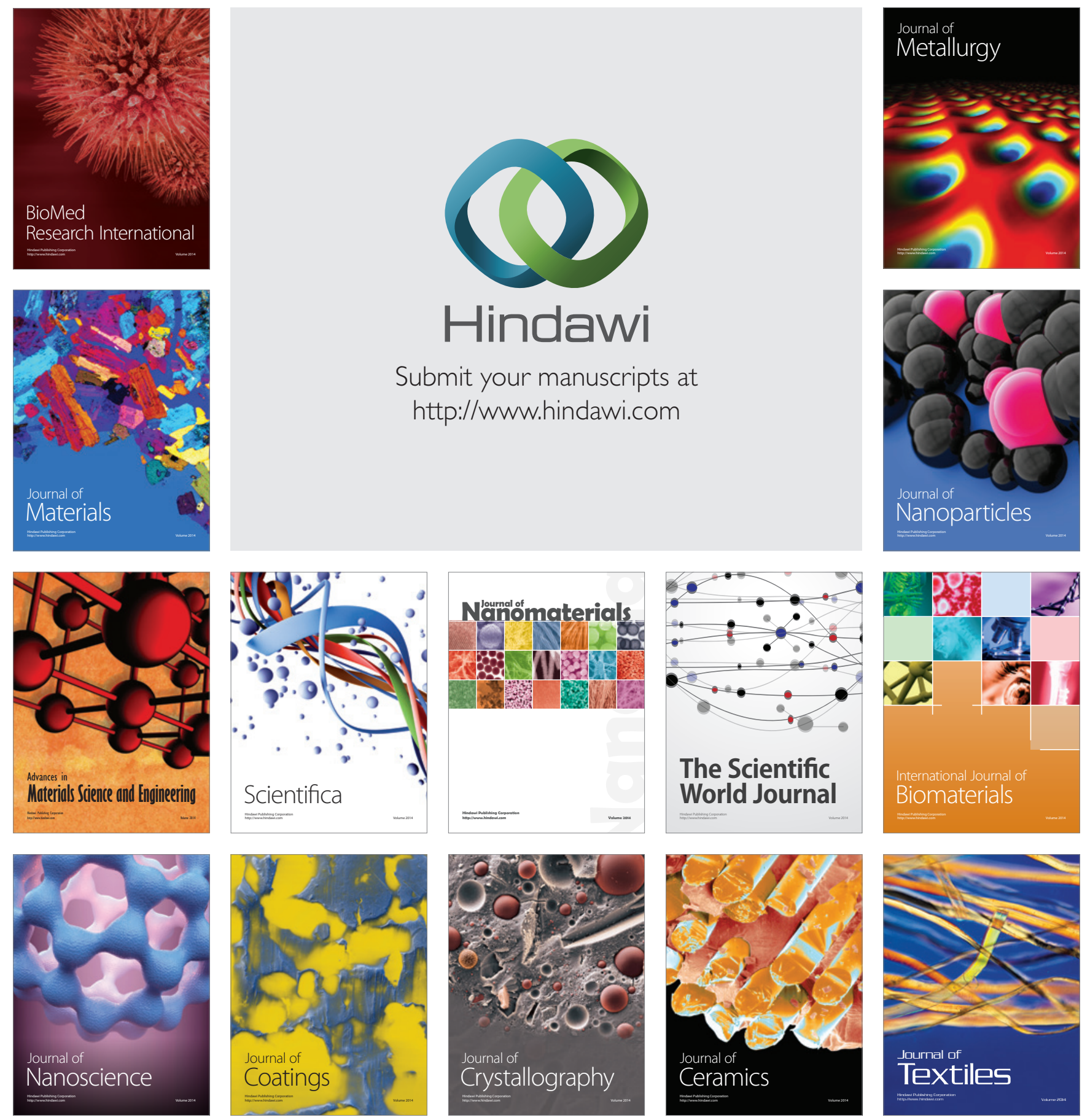